\title{
LEADERSHIP VALUES IN MADURASEE CULTURE
}

\author{
Ahmad Yusuf Sobri \\ Department of Educational Management, State University of Malang, Indonesia \\ ahmad.yusuf.fip@um.ac.id
}

\begin{abstract}
The research objectives were to describe cultures and leadership values in Madura culture, implications of leadership values espoused by Madura community in society collective life, and construction of leadership values applied by the Madura community in the life of modern society. The study used qualitative approach and hermeunetic. The found were: (1) cultural values of Madura society is shame culture, Islam, deliberation and consensus, and the leadership values is the concept of bhирра' bhabhu' ghuru rato, (2) Madura society leadership values has implications for collective life in society by making modifications on the structure of the concept of structuring such compliance, (3) construction of leadership values in modern Madura society according to concept of bhuppa' bhabhu' ghuru rato.
\end{abstract}

Keywords: leadership values, Madura culture

\section{INTRODUCTION}

Religious ethnic Madurese have been widely recognized as part of the religiousness of the Indonesian Muslims who hold fast to the Islamic tradition. However, it does not necessarily reflect the normative value of the religion. Understanding and interpretation of normative Islamic teachings on ethnic Madurese in its development goes hand in hand with its concrete cultural contextuality that is strongly influenced by the scope of locality and the time series that make up it (Rahman, 1994). In its manifestation, the communal ethnicity's religiousness appears to have appeared in the form of a local tradition in which Islam as a normative teaching and praxis forms a conception of reality that accommodates the sociocultural reality of its society or the community it establishes (Azra, 1999).

Madurese are known to have a distinctive culture, which has a cultural-specificity that is not similar to ethnography of other ethnic communities (Alwi, 2001). The cultural specificity appears to their obedience, submission, and resignation to the four major figures in life, namely buppa', babbu, guru, ban rato (father, mother, teacher, and leader of government). To the main figures that the Madurese adherence manifests itself in their socio-cultural life (Wiyata, 2003). Madurese ethnic compliance becomes a necessity to be actualized in daily praxis as a normative rule so that a intentionally violations of the rule causes the perpetrators to be subject to social and cultural sanctions. Actualization of compliance is done throughout his life. The most basic issue is the cultural meaning of compliance in the context of subordination, hegemony, exploitation, and losing positions throughout life.

The ethnic entity of Madura is also unique because it is a separate community that has different characteristics with other ethnics in the form and type of ethnography (Alwi, 2001). The uniqueness of Madurese culture seems to be inconsistent with its communal quantity which spread to various regions in Indonesia, ie 9.7 million people (7.5\%), ranked the largest ethnic quantity after Java (45\%) and Sunda (14\%) (Kompas , 24 Sept. 2005). Although the two conceptions do not seem to be aligned but the reality reflects that condition. The culture is basically shaped and influenced by the geographical and topographical conditions of hydraulic and rainfed agriculture land that tends to be barren so that the survival of their lives more as the main livelihood. They are shaped by a challenging and risky maritime life that gives rise to a high degree of mental and physical courage, hardhearted and resilient, confident, defensive in dangerous and precarious situations, open-minded, straightforward in speech, and upholding dignity and self-esteem.

Madura cultural wisdom is also a unique behavior in maintaining a true brotherhood. It is depicted from the culture expression: oreng dhaddhi taretan, taretan dhaddhi oreng (others can be as brothers themselves, while the brothers themselves can be as someone else). The uniqueness that emerges from the cultural expression (pseudo-kinship) is manifested in the form of actual behavior. This cultural expression means that compatibility in friendship or brotherhood can be firmly and eternally confirmed. That is, others who behave in line with the basic character of ethnic Madurese can easily be treated as siblings (pseudokinship). Conversely, siblings can be treated as someone else if they often experience discrepancies in opinions, views, and stances (Wiyata, 2005, Astro, 2006).

\section{METHODS}

This research uses qualitative approach to answer the problem of research comprehensively (Bogdan \& Biklen, 1998; Yin, 1999). In this study researchers act as instruments and data collection. This study aims to obtain a clear and detailed description of leadership values in Madurese culture. The type of this research is sociological phenomenological research. The researcher acts as a participant observer with moderate participation type. The research location was conducted in Pamekasan Regency with consideration: Pamekasan Regency is in the middle of Madura culture which divides Madura culture into two sub-cultures (East Madura culture and West Madura culture), and Pamekasan Regency is Madura Residency (Madurese government center) during colonial era.

The data source consists of human and nonhuman data. Sources of human data include Madurese cultural experts and Madurese leaders (in formal and informal institutions). While non-human data sources include literature and printed materials that contain 
Madurese cultural values and leadership values applied and developed in Madurese society. The data collection is done in stages, which is to study various literatures about Madurese cultural values and leadership values applied in Madurese society, and search for sources of data or informants. Data collection is done by snowball technique. Data collection techniques use interview, observation and documentation.

Data analysis was done by content analysis method and qualitative approach. Qualitative data analysis is done through the research stage, namely: determination of research focus, preparation of findings, making the next data collection plan based on findings from previous data collection, development of analytic questions to collect the next data, and determination of the next data collection target (Bogdan \& Biklen, 1998; Miles \& Huberman, 1984). Verification of the validity of findings through: (1) credibility, using data source triangulation techniques, (2) dependability, enlisting the help of experts and people who understand the research, and (3) confirmability, re-examining the data obtained by requesting further confirmation to informants.

\section{Results}

\section{RESULTS AND DISCUSSION}

Community perceptions of Madura name often confounded. This is due to the understanding based on language, race, ethnicity, culture, ethnicity and there is also a sense of Madura based on belief or religion is Islam. Based on the phenomenon has caused a negative stereotype, which is a description of outsiders who describe the Madurese negatively, such as hard, rude, irritable, killing, vengeful, and intolerant of others. Even the Madurese people are often used as a joke and laughing in the language of advertising or jokes on television. Ethnic have special characteristics that distinguish it from other ethnic. The Madurese have different identities with other ethnic groups. There are several cultural identities of the Madurese, namely the culture of shame, Islam, deliberation and consensus. Many observers of Madurese culture and society often misunderstand Madura, as they do not fully study Madura culture as a whole. As a result, clashes of understanding occurred and misunderstandings about Madura appeared everywhere.

Another culture adopted by the Madurese is Islam. The Madurese will not be angry if they say fools by outsiders. However, Madurese will make a great reaction if they are said to be not Muslims. The meaning of non-Muslims for the Madurese is that unbelievers and infidels will be eternal in hell. Islam and the Madurese are an inseparable unity. Both elements are mutually determinative. Membership of a person in the Madurese ethnic group is largely determined by the inclusion of an Islamic identity to that person. That is, if there are people Madura is not Muslim, then he is no longer referred to as a Madurese. In the life of the Madurese, for example in marriage, death, parties, home construction, farming, Madurese are always deliberate, both with family, peers even with religious leaders to obtain consensus. In marriage, for example, the date determination always conferred with the woman's parents and asked for clues from religious leaders. In working there is always cooperation (song-osong lombhung/ghutong rojhung) and in government there are always negotiations (rembuk desa), and so on.

Various descriptions of cultural values that have been described that the ancestors of the Madurese still had time to think about his offspring. In harmony with the development of Madurese ethnic culture came the formulation of the teaching of bhuppa 'bhabhu' ghuru rato. Implementation of these teachings for many years has been carried out by the people of Madura consequently so that eventually the teachings tend to be a teaching of traditional authority for the Madurese community. With these teachings, especially for the younger generation Madura is perceived as the doctrine of selfless devotion. Such teachings or principles require high dedication from society. Such devotion must start from the home environment, ie obedience to both parents (father and mother), then to the teacher (religious and formal) and then to the legitimate government. These values of obedience (bhuppa 'bhabhu' ghuru rato) can be regarded as the values of leadership applied in Madurese society.

The socio-cultural life of the Madurese community currently has a referential standard of adherence to the main figures, namely bhuppa 'bhabhu' ghuru rato. The concept of bhuppa 'bhabhu' ghuru rato is the collective life of Madurese society that lasted for a relatively long period of history. There is determination of the structure that settles in the cognitive and mental consciousness of the Madurese so that they must obey the main figures in a hierarchical manner. However, in its development Madurese creatively restructured the structure so that there are modifications in the concept of compliance.

Madurese community is known as a community that obeys in running the religion of Islam. Therefore Madura can be said to be identical with Islam, although not all Madurese are Muslims. In other words, Islam is a part of ethnic identity. Thus, as a Madurese religion, Islam not only serves as a reference of social behavior in people's lives. However, Islam is also one of the elements of ethnic identity marker Madura. Both elements are mutually determinant of the membership of a person in the ethnic group of Madura is largely determined by the ownership of Islamic identity on the person. Therefore it can be said that the culture that developed in Madura is a representation of Islamic values.

The culture of the Madurese to this day is a tribute to the pillars of the Madura culture, the bhuppa (bapak), bhabhu (mother), ghuru (teacher), rato (government). This phrase often appears in the daily association of Madurese society. If observed, the concept of bhuppa 'bhabhu' ghuru rato contains an understanding of the hierarchy of figures that must be respected and obeyed, ranging from father, mother, teacher and government. In accordance with the time that the younger generation should live, the concept of bhuppa 'bhabhu' in the past as a baptist of obedience to parents can now be changed into a family education 
center, like a breeding ground. With the position of a breeding center or an early educator in the family, the concept of bhuppa 'bhabhu' in the present is required to change the attitude that his command must always be followed into an early protective for his children and all members of his family and avoid the feeling of children as child domestic servants because every day they are closer to them than with their bhuppa 'bhabhu'.

The teacher (ghuru) is closely related to the education of both formal and non-formal institutions such as ustadzah and kyai. Classic description says that the ghuru is a figure to be obeyed and imitated. This jabaran is derived from the Hindu era that was taken over by Islam in Madura. In the classical period, the cantrik (students) sit cross-legged obediently in listening to the lessons of Pandita (ghuru). The lesson of Pandita is like the word of the king, the magic is the true word of the king, no need to be reviewed and interpreted. Obligations of students only remember and implement the teachings. In such circumstances Madurese people for a long time are really obedient and obedient to the ghuru, even the Madurese tend to do the cult of the ghuru. All what comes from the teacher must be respected, even the ghuru spit is believed to be qualified when he steps on it.

While the teachers in religious matters are ustadz (religious educators) and kyai (pesantren leader). The commonly used religious symbol is kyai who is not only a religious leader but also an informal leader for the community. The dominant kyai leadership places pesantren education institutions as a decisive position in the community and plays an active role in development. The role of such ghuru or kyai is a revolution by the ghuru itself. The role of ghuru from time to time is patience, patience and obedience in providing lessons that have been implemented in a regular and consistent.

As the last figure in the teaching of bhuppa 'bhabhu' ghuru rato is rato (government). Before independence Indonesia, rato is very instrumental in the life of Madurese. The devotion of the Madurese to rato is equal to their devotion to bhuppa 'bhabhu' and ghuru. Reformation on rato is faster than the other strata, especially after Indonesia's independence. The liberal nature of change to democracy has transformed almost all social fields including Madurese. The young generation of Madura began to understand the laws, rules and regulations of nation and state. All their behaviors are endeavored in accordance with such laws, rules and regulations. This is in accordance with the government's advice (rato) that every citizen should be able to demonstrate as a law-abiding citizen that follows the rules set by the government and is useful to the nation, state and religion.

In the devotion to advanced Madura, the younger generation of Madura must also try to maintain order if Madura wants to change with positive stereotype. As a younger generation of Islamic Madurese, efforts to realize order in all fields are also not easily dependent morality Madura human itself. Therefore, it is necessary to get in the orderly manner.
With that order, then it is a devotion to rato (government).

\section{Discussion}

In the socio-cultural life of the Madurese community, there is currently a referential standard of adherence to the main hierarchical figures, namely bhuppa 'bhabhu' ghuru rato. The concept of bhuppa 'bhabhu' ghuru rato is the collective life of Madurese society that lasted for a relatively long period of history. There is a determination of the structure that exists in the cognitive and mental consciousness of the Madurese so that they must obey the main figures in a hierarchical manner. However, in the next development Madurese society creatively structuring the force structure so that there are modifications in the concept of compliance.

The Madurese are known as a community that adheres to the practice of Islam (Jonge, 1989; Kusuma, 2003). Therefore, Madura can be said to be identical with Islam, although not all Madurese are Muslims. In other words, Islam is a part of ethnic identity. Thus, as a Madurese religion, Islam not only serves as a reference of social behavior in people's lives. However, Islam is also one of the elements of ethnic identity marker Madura. Both elements are mutually determinant of one's membership in the Madurese ethnic group. Therefore it can be said that the culture that developed in Madura is a representation of Islamic values.

One of the cultures that developed in Madurese society is a high respect for the pillars of the Madura culture buffer, namely bhuppa (father), bhabhu (mother), ghuru (teacher), rato (government). This phrase often appears in everyday social intercourse in Madurese society. The concept of bhuppa 'bhabhu' ghuru rato implies a hierarchy of figures that must be respected and obeyed, starting from father, mother, teacher and government. In other words, in the sociocultural life of Madurese society there is a referential standard of adherence to the main figures in a hierarchical manner. This normative construction binds every Madurese person, so that the abuses against him will be subject to social and cultural sanctions. As Geertz (1973) says human and cultural relations are like animals trapped by their own webs. Culture is an idea laid out in a symbol system that enables every individual to live in the midst of the universe.

The concept of bhuppa 'bhabhu" ghuru rato is a collective life construction that lasted for a relatively long historical period. It is produced by and at the same time produces social life, so it becomes a structure or strength that structuring the social structure (structuring structure), as well as a structured structure of the social world. In this connection, obedience to parents (father and mother) is given because there is a religious-cultural structure that structures religious and cultural obligations and ethics because they have delivered and nurtured a person into adulthood.

Similarly, the placement of the term bhuppa at the beginning of the bhuppa bhuphu ghuru rato compliance chain is structurally due to the position of the father himself. This position can be traced to the 
kinship and familial system of the Madurese. The kinship system in Madura is described as a bilateral system that does not emphasize the father or mother line. However, in this system there is an asymmetric tendency. In this case Neihof (in Sidiq, 2003) states that in lineage, maternal bloodline (pancer bine) is considered non-existent. The children of one father, although born by some mothers (taretan sapancer) are said to be closer than the children of one mother of several fathers (taretan dhangaso).

The patriarchal cultural system that developed in Madura also became a socio-religious structure that established the position of the father as the first person to be respected. Patriarchy is a social system that supports and justifies male domination, resulting in a concentration of power and immunity in the hands of men and resulted in the control and subordination of women and creating social imbalances between sexes (Subandi \& Suranto, 1998). In other words, patriaekhis culture is the social habits of the social heritage by positioning men as rulers or dominating women in the joints of social life. Culturally, the patriarchal system is a social construction of the gender relations between men and women. These social constructions can be societal assumptions, myths of gender relations and can be habits considered as fairness applied in social life. Religious power also contributes to the establishment of the father position in the first place of the people to obey. The legitimacy of this religion became the early history of the emergence of patriarchal culture in the life of society. This arises from the belief in God in a religion, and then comes the impression that has been imprinted in the subconscious of society that God is male.

Whereas the placement of bhabbu (mother) in the second sequence can not really be separated from the problems of women who are under the hegemony of men as seen from the above description. However, Madurese construct structures (structured structure) that develop so that Madurese women have a special value in Madurese society and culture. The special value is tangible more attention to girls than boys. Particular attention can be seen in the elements of Madurese culture, such as settlement structures and inheritance systems. Traditional settlement patterns of Madurese are manifested in tanean lanjang (a large courtyard of several houses in one kinship). The row of houses built in the settlement is for the children of the victims. Each of its inhabitants is bound by a kinship relationship. If the child is married then married, then the husband will settle in the house that has been provided by the parents of women (matrilokal). Instead, boys will be out of the house after they get married and settle in the house provided by the women's parents. In this case, boys do not have a special place in their family or their nuclear family.

Similarly, in terms of inheritance of family property. Even though Madurese are Muslim, the rules of inheritance follow the local customary system. The estate is divided when the parents are alive. In general, women will earn a larger share than men. Inheritance such as houses and yard, generally given to women and should not be sold to anyone. While the land of the field (teghalan) is given to the boy and may be sold to others. In the case of this division of inheritance, it is rare for men to get more parts. This part of the girl is more because women will be the place for her brother to pass in case of divorce or other cases. The position of such women makes Madurese society very dignified and respected women. In Madurese's view, women, especially wives, are a symbol of honor of a household or a Madurese man. Disorders of wives or women are interpreted as Madurese self-esteem abuse. This case is very potential leads to the occurrence of carok (Wiyata, 2002).

Even when being a mother, she is very influential in the child's life. He is greatly appreciated as a child should respect the father. But it seems that the sanctity of honor to the mother has a higher value so that the mother seems more respected than the father. The attitude of respect that grows from a child to a mother is made by a very close inner relationship. As a close proof of this relationship it is believed that the umbilical cord (tamoni) is an important aspect of birth because through the placenta a child relates to her mother in both inner and outer connection. The Madurese also gave high salaries to the teachers. In this case, the teacher is interpreted as kyai or ulama, who has taught the religious sciences to his santrinya. A kyai will have a high charisma if kekyaiannya obtained through achievement and through offspring. But if the two things can not be achieved at once, then the nasab path is very possible to be taken. Therefore, not a few kyais develop an established tradition, that their offspring have a great opportunity to become kyais. Following the conceptions of the concentric circle of Javanese power of Mataram II heritage, the offspring of small kyai semen have been legitimized that they can inherit some of the spiritual attributes of his father, the kyai. This legitimacy then becomes a common judgment that is continuously reproduced by santri and kyai close people so that it survives and survives in society.

Kyai is considered close to the sanctity of Islam so he is respected and imitated. The level of respect and adherence of Madurese to a kyai is manifested in the form of moral and material support, namely in the form of material giving. For example, when members of the community, especially retired santri, visit (sowan) to residence (dhalem) kyai to visit their children, almost certainly they give money (nyabis) or carry luggage. Madurese people, especially rural communities, construct kyai are worldly leaders as well as ukhrawi, or in other words as God's representative on earth (Anderson, 1972). This is probably not much different from that of the people in the past that a king is a symbol of the power of the microcosm and the macrocosm. The king in Javanese cosmology is believed to be the one who acquires the whisper of the heavens so that he possesses the perfection, the supernatural powers, and the enormous power to exercise power, namely to maintain tata tentrem kerta raharja.

Therefore, in the Madurese community kyai be a place to complain and ask for advice on various affairs in everyday life. Various public affairs, such as 
agriculture, illness, matchmaking, seeking fortune, building a home, finding a job and a career are often discharged to kyais. In other words, there is the need of the community especially the santri to always be close to the kyai. In addition, kyai has a place in the hearts of the Madurese community, as well as supported by structured strength and structured strength, in the form of ecological conditions and patterns of local settlements (Kuntowijoyo, 2002). The moor ecological conditions in Madura form the pattern of population settlement. The structure of the settlement in Madura is different from that of Java. The pattern of settlements in a village or village in Madura, especially in the interior area ideally consists of isolated units that are remote and centralized (nucleated). This means that people build houses in Madura in a yard of four or five brothers, surrounded by a green fence called kampong meji. Some of these hamlets are forming small villages, and some of these small villages will form villages. They are separated, but have a common religious center, either in the form of langgar, langgar rajeh, or mosque led by a kyai.

Of course, the majority of villages within the island of Madura approach this model. But the arrangement of villages or small villages is very diverse. Some villages or small villages are residential tapes (ribbons) that form a linear garus along a small lane. In areas with lots of paddy fields, the residential tape in many cases is the main feature. When rice fields are only a small part of the village land, the tape settlements tend to be replaced by clusters of distant (remote) homes but still along the path. In either case, the village or village does not form a unified and unified settlement. Some small villages or villages are built on the availability of highlands chosen by the population to build houses, so the groups of the settlements are not connected. This trend also applies in hilly areas, which is the back part of the Madura archipelago. In some villages or small villages, separate or isolated settlement groups depend on proximity to rice fields or fields.

Such conditions, then gave birth to a social organization based on religious and kyai authority. Kyai is the glue of solidarity and religious ritual activities, the builder of religious collective sentiments, and the unifying of social elements or kinship groups scattered due to the ecological factors and the pattern of the settlement.

Finally, the Madurese give rato a tribute and obedience. Rato in this case means a formal leader. In subsequent developments, Madurese structured structures so that they more broadly made categories that could be used as a benchmark for Madurese respect and compliance, including respect for and adherence to formal leaders. The first category is courtesy. Modesty consists of knowing and following the rules of relationships between generations, by rank. People who do not appreciate such courtesy are called ta'taoh yuda negara (disrespect yuda negara). The term yuda is a symbol of the ruler, karana judging from its history Yuda Negara is the name of the regent of Sumenep who used to help in the battle of Trunojoyo against the Dutch colonizers. The second category, is respect for both yourself and others. Madurese prioritize respect and obedience much less to older or higher social status. The government, in the sense of people holding office in government, has a high social status in Madurese society. The high appreciation of government officials gave birth to the stigma that structured the Madurese that government officials regarded as oreng rajeh (influential people) or oreng cokop (people who live well). While the common people, such as farmers (including farm laborers) and traders (small traders) in Madurese society structure is at the lowest level (oreng kene).

\section{CONCLUSIONS AND RECOMMENDATIONS}

\section{Conclusions}

There are several cultural values and leadership embraced in Madurese culture, namely shame culture, Islam, and deliberation and consensus. While the values of leadership in Madurese culture is reflected from the teachings or concepts of bhuppa bhabhu ghuru rato, the hierarchy of obedience to the Father, Mother, Teacher and Government. The values of leadership held by the Madurese community in having implications on collective life in society. Compliance with key hierarchical figures, bhuppa bhabhu ghuru rato is the construction of collective life of Madurese society which takes place in a long history. Currently Madurese society creatively structuring the structure so that there are modifications in the concept of compliance. Construction of leadership values applied by Madurese society in the life of modern society in accordance with the teachings of bhuppa bhabhu ghuru rato. However, such teaching or concepts require reconstruction adapted to the present day.

\section{Recommendations}

Theorists who cultivate cultural issues. This research is expected to be the basis for the formulation of thesis on Madura cultural values and leadership values applied by Madurese society and the possibility of the tendency of Madura cultural change. Policymakers at the ranks of local leaders. This research can be used to develop development plans and empowerment of Madurese cultural community. Academics in the field of sociology of education, educational psychology and social psychology. This research is expected to be used as an enrichment material.

\section{REFERENCES}

[1] Alwi, H. 2001. Kamus Besar Bahasa Indonesia. Ed. III Jakarta: Depdiknas RI dan Balai Pustaka.

[2] Anderson, B. 1972. The Idea of Power in Javanese Culture. In Claire Holt (Ed.). Culture and Politics in Indonesia. Ithaca: Cornell University Press.

[3] Astro, M. M. 2006. Orang Madura peramah yang Sering Dikonotasikan Negatif. Retrieved December 27. 2016, from http://www.mamboteam.com.

[4] Azra, A. 1999. Konteks Berteologi di Indonesia: Pengalaman Islam. Cet. I. Jakarta: Paramadina. 
[5] Bogdan, R. C. \& Biklen, S. K. 1998. Qualitative Research In Education: An Introduction to Theory and Methods. Boston: Allyn and Bacon.

[6] Geertz, C. 1973. The Interpretation of Cultures. New York: Basic Book, Inc.

[7] Jonge, H. D. 1989. Madura dalam Empat Zaman Pedagang, Perkembangan Ekonomi dan Islam. Jakarta: PT Gramedia.

[8] Kuntowijoyo. 2002. Perubahan Sosial dalam Masyarakat Agraris Madura 1850-1940. Yogyakarta: Mata Bangsa.

[9] Kusuma, M.S. 2003. Sopan, Hormat dan Islam: Ciriciri Orang Madura. In Soegianto (Ed.). Kepercayaan, Magi dan Tradisi dalam Masyarakat Madura. Jember: Tapal Kuda.
[10] Rahman, F. 1999. Islam and Modernity: Transformation of an Intellectual Tradition. Chicago: The university of Chicago Press.

[11] Sidiq, M. 2003. Kekerabatan dan Kekeluargaan Masyarakat Madura. In Soegianto (Ed.). Kepercayaan, Magi dan Tradisi dalam Masyarakat Madura. Jember: Tapal Kuda.

[12] Subandi, I. \& Suranto, H. 1998. Wanita dan Media. Jakarta: PT Remaja Rosdakarya.

[13] Wiyata, A.L. 2002. Carok, Konflik Kekerasan dan Harga Diri Orang Madura. Yogyakarta: LKiS.

[14] Wiyata, A. L. 2003. Madura yang Patuh? Kajian Antropologi Mengenai Budaya Madura. Jakarta: CERIC-FISIP UI.

[15] Wiyata, A. L. 2005. Model Rekonsiliasi Orang Madura. Retrieved December 27, 2016, from http://www.fisip.ui.edu/ceric. 